\title{
Diversity Shifts in the Mangrove Vegetation of the Rio del Rey- Estuary (Cameroon)
}

\author{
Guillaume Léopold Essomè-Koum ${ }^{1}$, Vanessa Maxémilie Ngo-Massou ${ }^{1,2}$, Ernest Flavien \\ Kottè-Mapoko ${ }^{1}$, Paul Bilong ${ }^{3}$, Ndongo Din ${ }^{1 *}$ \\ ${ }^{1 *}$ Department of Botany, Faculty of Science, the University of Douala, Cameroon \\ ${ }^{2}$ Department of Biological Sciences, High Teacher's Training College, University of Yaounde I, \\ Cameroon \\ ${ }^{3}$ Department of Earth Sciences, Faculty of Sciences, University of Yaounde I, Cameroon
}

\begin{abstract}
Rio del Rey Estuary mangroves are the most widespread in Cameroon but remain poorly known. This study aims to determine changes in the floristic composition and structure. The survey was conducted in seven localities of the $S W$ region. Transects were opened perpendicular to the main tidal channels. Sampling plots $(25 \mathrm{~m} \times 25 \mathrm{~m})$ were established to evaluate the structure of the vegetation. All African Atlantic mangroves characteristics species are present. Rhizophora spp. predominate as in most African stands. Floristic diversity was low and varied according to localities. The Shannon diversity index H' ranged from 0.34 to 1.91 and the Margalef specific richness index varied from 1.08 to 4.45 . The mean diameter was $20.38 \pm 18.79 \mathrm{~cm}$; and trees height ranged from 3.82 to $37 \mathrm{~m}$. The absolute density was $934.19 \pm 564.88 \mathrm{stem} \mathrm{ha}^{-1}$ and the basal area was $1.54 \pm 0.99 \mathrm{~m}^{2} \mathrm{ha}^{-1}$. In many cases, the diameter class distribution has shown characteristics of disturbed stands. The Newman-Keuls test has shown differences between plots. The sample unit sizes, the degree of vegetation evolution, the Nypa fruticans invasion and the anthropogenic activities extent affect significantly the characteristic of mangrove stands.
\end{abstract}

Keywords: anthropogenic activities, diversity, floristic composition, structural parameters.

\section{INTRODUCTION}

Mangrove forests cover an estimated 152361000 ha of the tropical and subtropical shorelines of the world $[1,2,3,4]$ and deliver important ecosystem functions, goods and services [5, 6]. Therefore, any loss of mangrove forest means a loss of subsistence and cash-based livelihoods and ecological and conservation function [7]. However, as a consequence of enormous anthropogenic pressure and multiple threats, western African mangroves have declined by $>25 \%$ over the past 25 years $[4,8]$ and 53.216 ha of the Cameroon's mangrove forests have been lost over the last 13 years $[3,9]$.

Although moderate natural expansion of mangrove has been reported in certain parts of the world [10, $11,12]$, this phenomenon is relatively rare in Africa [13] where mangrove deforestation and degradation still appears to be dominant $[1,14,15,16]$. It is now commonly recognized that mangrove wood harvesting is a core economic activity for coastal communities in Cameroon and the rest of Central and Western Africa [17, 18, 19, 20]. The unsustainable use of mangrove resources as a result of increasing population size and loss through ecosystems conversion for development activities is fragmenting and depleting this system on a large scale [21,22].

Anthropogenic pressures combined with climate change and sea-level rise, urge the need to conserve, protect, and restore tidal wetlands [23, 24]. However, knowing the exact specific composition of mangroves in a country is important and is a prerequisite for understanding all aspects of the structure and function of mangroves as well as their bio-geographical affinity for their conservation and management [25].

Cameroon mangrove forests are divided into two major groups on which the Rio del Rey stands is the most widespread. These ecosystems do not take advantage of the biological diversity conservation laws, even for those that are located in a natural reserve. Due to the lack of policy regulation in the management of coastal ecosystems, anthropogenic activities play a major role in reducing mangrove biodiversity and provision of ecosystem services [20, 26, 27]. 
The development of strategies for sustainable management of these ecosystems requires a good knowledge of their structure, composition and ecology [28]. Actually, the mangrove ecosystem of the Cameroon estuary has been mainly studied $[9,18,20,27,29,30,31,32,33,34,35,36]$, but the Rio del Rey ecosystem remains poorly known because of the distance and especially the Bakassi border army conflict between Cameroon and Nigeria [37].

The recent end of the above conflict has favored the implementation of research surveys $[19,32,38$, $39,40]$. The structure and composition of the near shore mangroves have been affected by coastal erosion and climate change [32]. The last phenomenon is supposed to be worsen in mangrove ecosystem worldwide. Before estimating the impact of coastal hazards on the alteration of local ecosystems, the diversity of these areas must be known in order to prepare further adaptation measures. The objective of this study is to evaluate the spatial variation in the structure and the composition of mangrove vegetation between seven sites of the Rio del Rey estuary.

\section{Material AND Methods}

\subsection{Study Site}

This study was carried out in seven localities of the Ndian Division in the South West Region (SWR) of Cameroon (Figure 1). The coastal border of the SWR falls along the Gulf of Guinea in Western Africa. The climate is an especial equatorial type strongly influenced by the proximity of Mount Cameroon $(4095 \mathrm{~m})$, the highest peak in West and Central Africa. The average annual rainfall ranges from $5000 \mathrm{~mm}$ to $10000 \mathrm{~mm}$ with the number of rainy days' approaches 250 [37]. The mean annual temperature ranges from $25.5^{\circ} \mathrm{C}$ to $27^{\circ} \mathrm{C}[19,37]$.

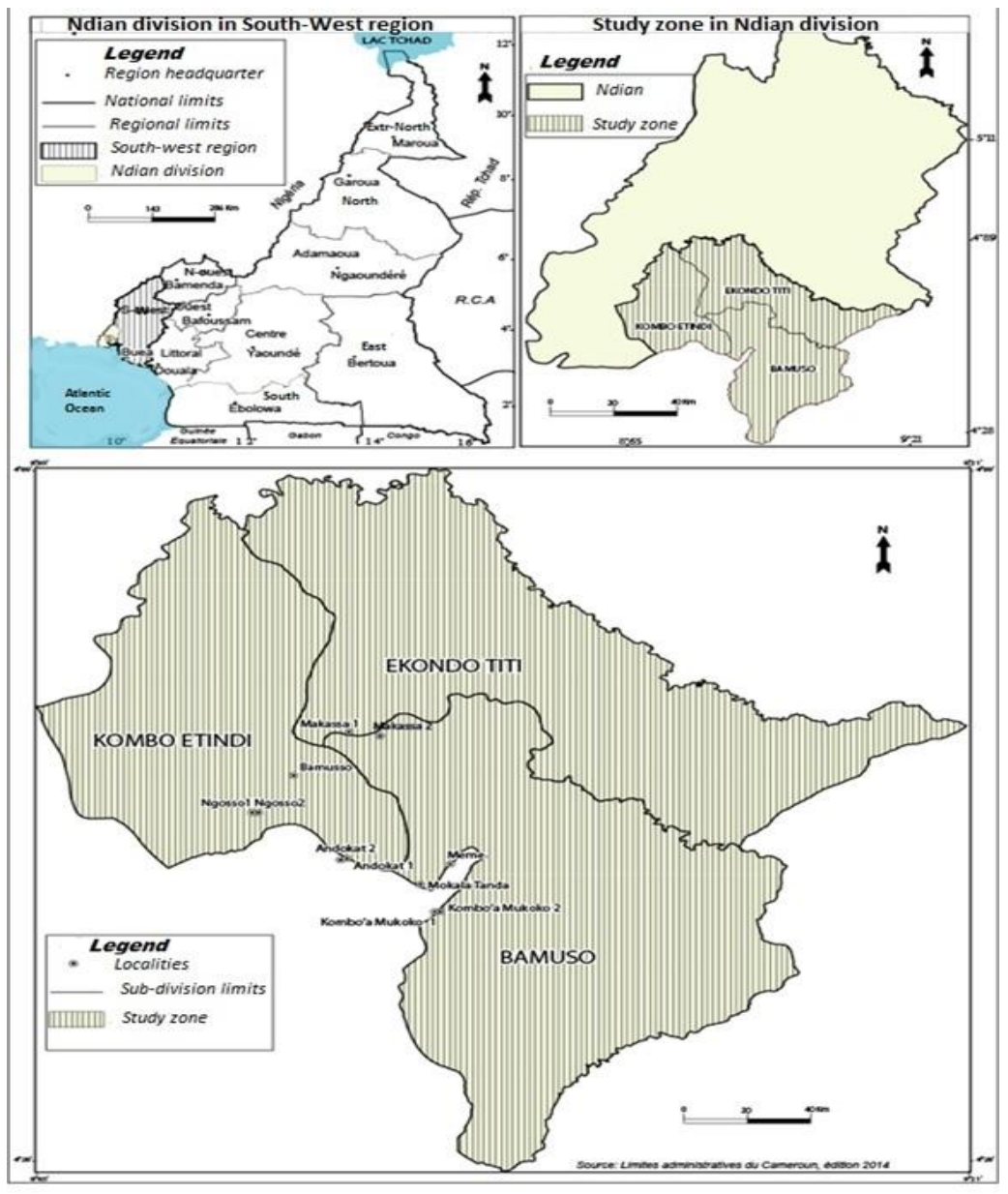

Figure1. Localities of study in the mangroves of the Rio del Rey estuary

\subsection{Data Collection}

In each locality, transects were opened perpendicular to the main channels, from water to landward in order to access homogenous stands of Rhizophora spp. and from land to water channels for assessing mixed vegetation stands. After this operation, all species along the trail have been identified and vegetation zone determined. Inside every homogenous band, a plot of $25 \times 25 \mathrm{~m}^{2}$ was established 
occupying each side of the trail evenly. The coordinates of each plot were recorded using a GPS "etrex Garmin".

According to the vegetation structure, eleven plots were established in Andokat (2), Bamusso (1), Kombo'a Mukoko (2), Massaka (2), Meme (1), Ngosso (2) and Mukala Tanda (1). Six of the plots were established in a homogeneous band of Rhizophora spp., four in a mixed zone of Rhizophora spp. and Avicennia germinans. The last plot in which Rhizophora was not present was examined to estimate the characteristics of the trees without the influence of the predominant species. All trees with stem circumference $>15 \mathrm{~cm}$ were sampled. The circumference measurements were taken over the stilt roots for Rhizophora trees and at $1.30 \mathrm{~m}$ above the ground for other tree species by using a plastic measure tape of $150 \mathrm{~cm}$ or $5 \mathrm{~m}$. The previous operation was coupled with the measure of distance between neighboring trees with a decameter tape. Height measurements were conducted using Suunto Clinometer [19].

\subsection{Data Analysis}

Species richness indexes and structure parameters were calculated from field data using classic formula $[9,41]$. Thus, the diameter $(D)$, the absolute density $(D a)$ and the basal area $(B a)$ were obtained from the tree circumference measures. Relationship between plant structural parameters (DBH, height, basal area, density, distance between trees) were establish. Regression equations were assessed using the number of individuals, the mean tree diameter, the mean distance between trees and the density of plots. The Newman-Keuls test was used to compare the structure of the diameters at different sites or plots. They were performed using STATISTICA 10 software.

\section{RESUlTS AND DISCUSSION}

\subsection{Species Richness}

The plant survey conducted in the open transects in each community permitted to identify 21 species and 19 genus belonging to 11 families (Table 1). The most represented family is Fabaceae (five species). Then comes Arecaceae, Combretaceae, Rhizophoraceae (three species) and finally seven families consist of a single species (Acanthaceae, Euphorbiaceae, Malpighiaceae, Malvaceae, Meliaceae, Pandanaceae and Pteridaceae). The distribution of species in communities occurs in localities as follows: 06 species (Andokat, Bamusso, Kombo'a Mukoko and Ngosso), 07 species (Massaka), 15 species (Mukala Tanda) and 18 species (Meme). The least diverse locality was Bamusso, while that of Meme had the greatest specific diversity.

Table1. Distribution of species in the sample localities. And, Andokat; Bam, Bamusso ; KoM, Kombo'a Mukoko; Mas, Massaka; Mem, Meme ; MuT, Mukala Tanda ; Ngo, Ngosso

\begin{tabular}{|c|c|c|c|c|c|c|c|c|}
\hline \multirow{2}{*}{ Species } & \multirow{2}{*}{ Families } & \multicolumn{7}{|c|}{ Localities } \\
\hline & & And & MuT & Mas & Ngo & Mem & Bam & KoM \\
\hline Acrostichum aureum Linn. & Pteridaceae & $\bullet$ & $\bullet$ & $\bullet$ & $\bullet$ & $\bullet$ & $\bullet$ & $\bullet$ \\
\hline Alchornea cordifolia Müll. Arg. & Euphorbiaceae & & & & & $\bullet$ & & \\
\hline Anthocleista vogelii Planch. & Combretaceae & & & & & - & & \\
\hline Avicennia germinans (L.) Stearn & Acanthaceae & $\bullet$ & $\bullet$ & $\bullet$ & & $\bullet$ & & \\
\hline Carapa procera $\mathrm{DC}$ & Meliaceae & & $\bullet$ & & & & & \\
\hline Conocarpus erectus Linn. & Combretaceae & & $\bullet$ & & & $\bullet$ & & \\
\hline Cynometra mannii Oliv. & Fabaceae & & & & & $\bullet$ & & \\
\hline Dalberbia ecastaphyllum Taub. & Fabaceae & $\bullet$ & $\bullet$ & $\bullet$ & $\bullet$ & $\bullet$ & $\bullet$ & $\bullet$ \\
\hline Drepanocarpus lunatus G. F. Meyer & Fabaceae & & $\bullet$ & & & $\bullet$ & & \\
\hline Guibourtia demeusei J. Leonard & Fabaceae & & $\bullet$ & & & & & \\
\hline Heteropteris leona (Cav.) Exell & Malpighiaceae & & & & & $\bullet$ & & \\
\hline Hibiscus tiliaceus Linn. & Malvaceae & & $\bullet$ & & & $\bullet$ & & \\
\hline Laguncularia racemosa Gaertn. & Combretaceae & & & & & $\bullet$ & & \\
\hline Nypa fruticans (Thurnb.) Wurmb. & Arecaceae & $\bullet$ & $\bullet$ & $\bullet$ & $\bullet$ & $\bullet$ & $\bullet$ & $\bullet$ \\
\hline Ormocarpum verrucosum P. Beauv. & Fabaceae & & & & & $\bullet$ & & \\
\hline Pandanus sabatiei Huynh & Pandanaceae & & $\bullet$ & & & & & \\
\hline Phoenix reclinata Jacq. & Arecaceae & & $\bullet$ & & & $\bullet$ & & \\
\hline Raphia palma-pinus Hutch. & Arecaceae & & $\bullet$ & & & $\bullet$ & & \\
\hline Rhizophora harrisonii Leechman & Rhizophoraceae & & $\bullet$ & $\bullet$ & $\bullet$ & $\bullet$ & $\bullet$ & $\bullet$ \\
\hline Rhizophora mangle L. & Rhizophoraceae & $\bullet$ & $\bullet$ & $\bullet$ & $\bullet$ & $\bullet$ & $\bullet$ & $\bullet$ \\
\hline Rhizophora racemosa Meyer & Rhizophoraceae & $\bullet$ & $\bullet$ & $\bullet$ & $\bullet$ & $\bullet$ & $\bullet$ & $\bullet$ \\
\hline
\end{tabular}


Floristic composition varies. Indeed, the inventory in communities makes it possible to identify globally not only the 06 species reported by [1] and 07 characteristic species highlighted by many authors for the mangroves of Cameroon [3, 37, 42, 43], but also the presence of accompanying species that some authors call related species. In addition, by including species not mentioned by [1], Acrostichum aureum, which is present and common in Cameroon mangroves, low species richness of Cameroon mangroves remains a reality. This situation was confirmed in this survey by a low index of specific richness of Margalef (S) which varies from 0.23 to 4.4 and a low Shannon diversity index (H') which ranged from 0.35 to 1.91 .

However, [29], justify the low diversity of the African Atlantic mangroves in that it could be related to a definition that does not analyze in an objective manner, the flora evolution in all regions. These authors and others $[44,45,46]$ add that no doubt hangs over membership of the mangrove species that [47] calls as major, but the exclusion of several species of this vegetation still lacks conclusive scientific evidence and confirms the lack of consensus expressed by some authors on their classification [44, 46, 48, 49, 50].

In addition, the predominance of the genus Rhizophora spp. with 85.82\%) (351 individuals) but also the species Avicennia germinans which represents (12.47\%) (51 individuals) confirms that the genera Rhizophora and Avicennia are most dominant in stands of mangroves in the world [51]. These two species represent $98.29 \%$ (402 individuals on 418 inventoried). Also, the percentage occupied by Rhizophora spp. corroborates with some authors who believe that this genus is most numerous in the Cameroon mangroves [1, 13, 18, 52, 53].

\subsection{Structure Parameters}

There is a variation of the structure parameters in the different stands (Table 2). In the plots of the monospecific Rhizophora spp. stand, the mean density $\left(744 \pm 386\right.$ stem ha $\left.^{-1}\right)$ and the mean diameter of the individuals $(15.61 \pm 5.44 \mathrm{~cm})$ were low. Also, the mean height was $(11.62 \pm 3.51 \mathrm{~m})$ and the mean distance between the trees was $2.98 \pm 0.54 \mathrm{~m}$. In mixed vegetation of Rhizophora spp. and A. germinans, the mean density $\left(444 \pm 160\right.$ stem ha $\left.^{-1}\right)$ was low but the mean diameter of the individuals $(35.17 \pm 11.82 \mathrm{~cm})$ was very high. Meanwhile, the mean height was $(21.19 \pm 5.76 \mathrm{~m})$ and the average distance between the trees $(4.89 \pm 1.33 \mathrm{~m})$ was also high. For the plot where Rhizophora spp. was absent, the structural parameters also differ from those of the first and second stands. The density (448 stem $\left.\mathrm{ha}^{-1}\right)$ was low whereas the mean diameter of individuals $(26.76 \pm 26.84 \mathrm{~cm})$, the average height $(15.74 \pm 8.89 \mathrm{~m})$ and the mean distance between the trees $(3.77 \pm 2.56 \mathrm{~m})$ were high.

The regression analysis has shown that there is a strong positive relationship between the mean diameter and the mean height of the trees $\left(\mathrm{R}^{2}=0.9369, \mathrm{n}=11\right)$, and the regression equation generated is of the type $y=9.5103 x-11.586$. There was also a relationship between mean height and mean diameter $\left(\mathrm{R}^{2}=0.9777, \mathrm{n}=11\right)$ and the regression equation generated is of the type $y=0.5005 x+3.5991$. Furthermore, the regression analysis shows also a negative relationship between the mean diameter and the number of individuals and between the mean distance and the density (Figure 2).

Table2. Structural attributes of the mangroves of the Rio del Rey estuary. Lat, Latitude; Lon, Longitude; NI, Number of individuals; NS, Number of species; MDis, Mean distance (m); MDia, Mean diameter (cm); MHei, Mean height (m); Den, Density (stem ha $\left.{ }^{-1}\right) ; B A$, Basal area $\left(m^{2} h a^{-1}\right)$

\begin{tabular}{|l|c|c|c|c|c|c|c|c|r|}
\hline \multirow{2}{*}{ Sites of plots } & \multicolumn{2}{|c|}{ Coordinates } & \multirow{2}{*}{ NI } & \multirow{2}{*}{ NS } & \multirow{2}{*}{ MDis } & \multirow{2}{*}{ MHei } & MDia & \multirow{2}{*}{ Den } & BA \\
\cline { 2 - 10 } & Lat. N & Lon. E & & & & & & & 1.21 \\
\hline Ngosso 1 & $4^{\circ} 33^{\prime} 52.23^{\prime \prime}$ & $8^{\circ} 47^{\prime} 13.35^{\prime \prime}$ & 31 & 1 & 3.47 & 14.54 & 22.28 & 496 & 15.02 \\
\hline Ngosso 2 & $4^{\circ} 33^{\prime} 50.82^{\prime \prime}$ & $8^{\circ} 47^{\prime} 12.49^{\prime \prime}$ & 40 & 1 & 3.58 & 10.53 & 15.02 & 640 & 0.71 \\
\hline Bamusso & $4^{\circ} 35^{\prime} 33.15^{\prime \prime}$ & $8^{\circ} 48^{\prime} 50.10^{\prime \prime}$ & 96 & 1 & 2.36 & 9.69 & 11.95 & 1536 & 1.08 \\
\hline Kombo'a Mukoko 1 & $4^{\circ} 28^{\prime} 57.54^{\prime \prime}$ & $8^{\circ} 54^{\prime} 5.78^{\prime \prime}$ & 19 & 1 & 2.13 & 5.77 & 6.52 & 304 & 0.06 \\
\hline Kombo'a Mukoko 2 & $4^{\circ} 28^{\prime} 59.9^{\prime \prime}$ & $8^{\circ} 54^{\prime} 4.31^{\prime \prime}$ & 44 & 1 & 3.23 & 16.67 & 21.63 & 704 & 1.62 \\
\hline Massaka 1 & $4^{\circ} 38^{\prime} 021^{\prime \prime}$ & $8^{\circ} 50^{\prime} 50.2^{\prime \prime}$ & 35 & 2 & 3.27 & 14.38 & 20.29 & 560 & 1.02 \\
\hline Massaka 2 & $4^{\circ} 37^{\prime} 58.7^{\prime \prime}$ & $8^{\circ} 52^{\prime} 18.6^{\prime \prime}$ & 49 & 1 & 2.97 & 12.52 & 16.29 & 784 & 1.13 \\
\hline Andokat 1 & $4^{\circ} 31^{\prime} 38.3^{\prime \prime}$ & $8^{\circ} 51^{\prime} 24.4^{\prime \prime}$ & 16 & 2 & 5.51 & 25.74 & 45 & 256 & 2.54 \\
\hline Andokat 2 & $4^{\circ} 31^{\prime} 38.3^{\prime \prime}$ & $8^{\circ} 51^{\prime} 24.4^{\prime \prime}$ & 20 & 2 & 6.64 & 27.94 & 48.4 & 320 & 3.68 \\
\hline Meme & $4^{\circ} 31^{\prime} 25.5^{\prime \prime}$ & $8^{\circ} 54^{\prime} 25.2^{\prime \prime}$ & 40 & 2 & 3.96 & 16.70 & 27.01 & 640 & 2.29 \\
\hline Mukala Tanda & $4^{\circ} 30^{\prime} 20.6^{\prime \prime}$ & $8^{\circ} 53^{\prime} 42.4^{\prime \prime}$ & 28 & 4 & 3.74 & 15.74 & 26.76 & 448 & 1.57 \\
\hline
\end{tabular}




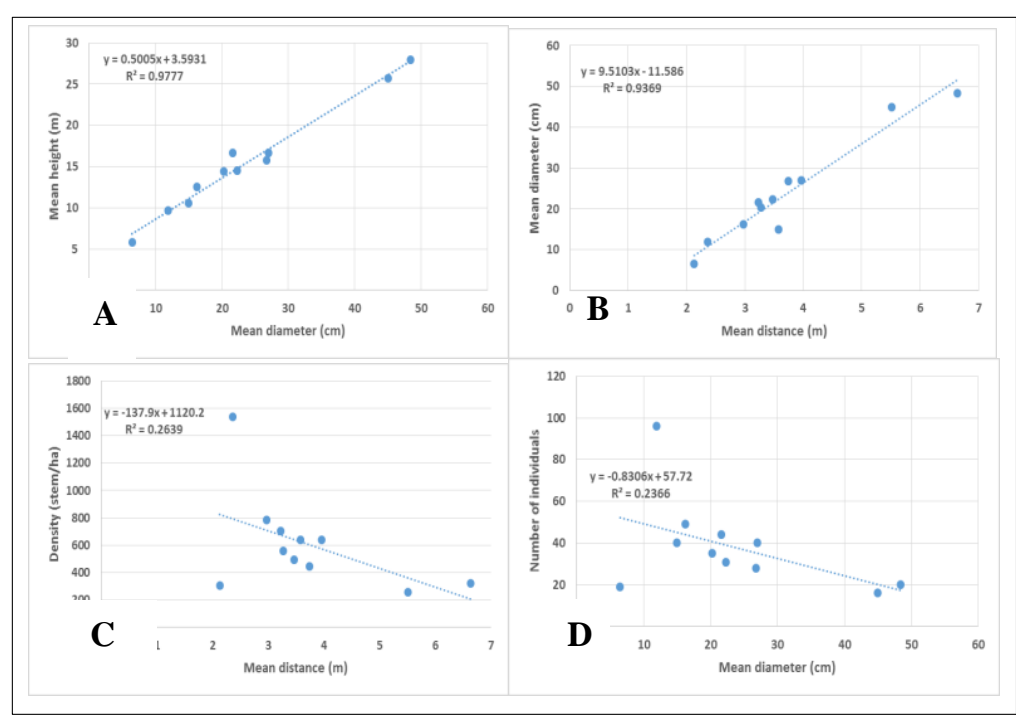

Figure2. Relationship between some structure parameters: A, mean height vs. mean diameter; B, mean diameter vs. mean distance; $\boldsymbol{C}$, density vs. mean distance; $\boldsymbol{D}$, number of individuals vs. mean distance. The equation and the correlation coefficient $\left(R^{2}\right)$ are given in each case

The basal area as well as diameter is a good parameter to express the level of development of a stand [54]. In monoculture plots of Rhizophora spp., structural parameters are variable. The density and the basal area varied from 304-1536 stem ha ${ }^{-1}$ and from 0.06 to $1.62 \mathrm{~m}^{2} \mathrm{ha}^{-1}$ respectively. In mixed plots of Rhizophora spp. and A. germinans, structural attributes ranged from 256-640 stem ha ${ }^{-1}$ for the density and the basal area of 1.13 to $3.68 \mathrm{~m}^{2} \mathrm{ha}^{-1}$. In the plot where the predominant species Rhizophora spp. is absent, the density is 448 stem ha $^{-1}$ and the basal area of $1.57 \mathrm{~m}^{2} \mathrm{ha}^{-1}$. Overall, the structural parameters are close to those obtained by [38] in the mangrove of Bamusso in Cameroon. On the other hand the results of the densities and the basal areas were lower than those obtained by [19] in the mangroves of SW Cameroon. Our results of these two structural parameters are also lower than those obtained by [55] in mangroves of Tudor Creek in Kenya and those of [56] in the mangroves of India.

In some plots of pure stands of Rhizophora spp., analysis of the distribution of diameter classes shows a disturbed stand. Some classes are absent and young individuals are not always the most abundant. In plots of mixed stands and in those where the predominant species was not present (Masaka 1, Andokat 1, Andokat 2, Meme and Mukala Tanda), all classes are present but younger individuals are not always the most represented (Figure 3). Theoretically, in an uneven-aged forest there is a normal series of age-gradations, depicted by the reversed $\mathbf{J}$ curve [55]. This normal situation in size classes is observed in our survey only on the site of plot Bamusso. The distribution of diameter size classes in the ten other sites of plots indicates a forest disturbance regime according to direct needs by the people. According to [55], this forest disturbance revealed a lack of a harvesting plan, resulting in a haphazard spatial distribution of different size classes, with a highly selective graphical frequency distribution. Likewise, as a consequence of tree harvesting, the proliferation of Nypa fruticans induced the disturbance of the vegetation structure of the Cameroon mangroves [37].

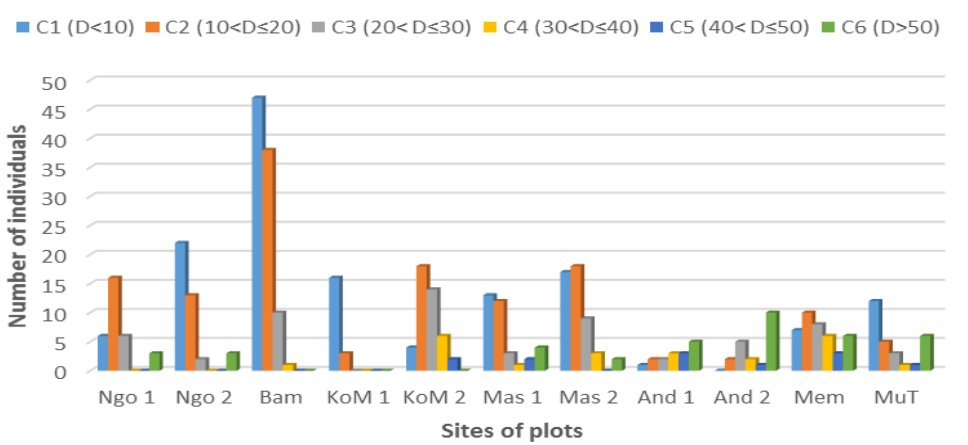

Figure3. Number of individuals per diameter class in the sites of plots. And 1, Andokat 1; And 2, Andokat 2; Bam, Bamusso; KoM 1, Kombo'a Mukoko 1; KoM 2, Kombo'a Mukoko 2; Mas 1, Massaka 1; Mas 2, Massaka 2; Mem, Meme; MuT, Mukala Tanda; Ngo1, Ngosso 1; Ngo 2, Ngosso 2 
In the monospecific plots of Rhizophora spp., the mean diameter is low $(15.61 \pm 5.44 \mathrm{~cm})$. There are very few trees with a large diameter $(\mathrm{D}>20 \mathrm{~cm})$ that close the opening of the canopy. In addition, there is strong intraspecific competition that limits the density of individuals at the adult stage. It is noted that individuals of class I $(\mathrm{D}<10 \mathrm{~cm})$, with a proportion of $44.81 \%$, are by far the most dominant of the diametric structure of this stand. In contrast, in mixed plots of Rhizophora spp. and A. germinans, the mean diameter is great $(35.17 \pm 11.83 \mathrm{~cm})$. Trees with large diameters $(\mathrm{D}>20 \mathrm{~cm})$, with a proportion of $63.33 \%$, are the most dominant of the diametric structure of this stand. In the plot where the predominant species is absent, the mean diameter is large $(26.76 \pm 26.35 \mathrm{~cm})$. Despite the presence of a few stem of Drepanocarpus lunatus and Pandanus candelabrum, trees with large diameters $(\mathrm{D}>20 \mathrm{~cm})$, with a proportion of $33.33 \%$, are not the most dominant of the diametric structure of the stand.

Allometric relationships in the mangroves are of considerable interest [30]. The present study has shown strong positive relationships on the one hand between mean diameter and mean distance of the trees and on the other hand between mean height and mean diameter.

Statistical analysis of the diameter distribution showed that sites of plots 8 (Andokat 1) and 9 (Andokat 2) are significantly different from other. Thus, $F(10,407)=15.445$ at $p=0.0000$. Otherwise, the block 1 (Ngosso 1, Ngosso 2, Bamusso and Kombo'a Mukoko 1), block 2 (Kombo'a Mukoko 2, Massaka 1 and Massaka 2) and the block 4 (Meme and Mukala Tanda) are different (Figure 4). But the 'Newman-Keuls post hoc test' showed that they are not significantly different; meanwhile, this test confirms that the blocks 1,2 and 4 are significantly different from block 3 .

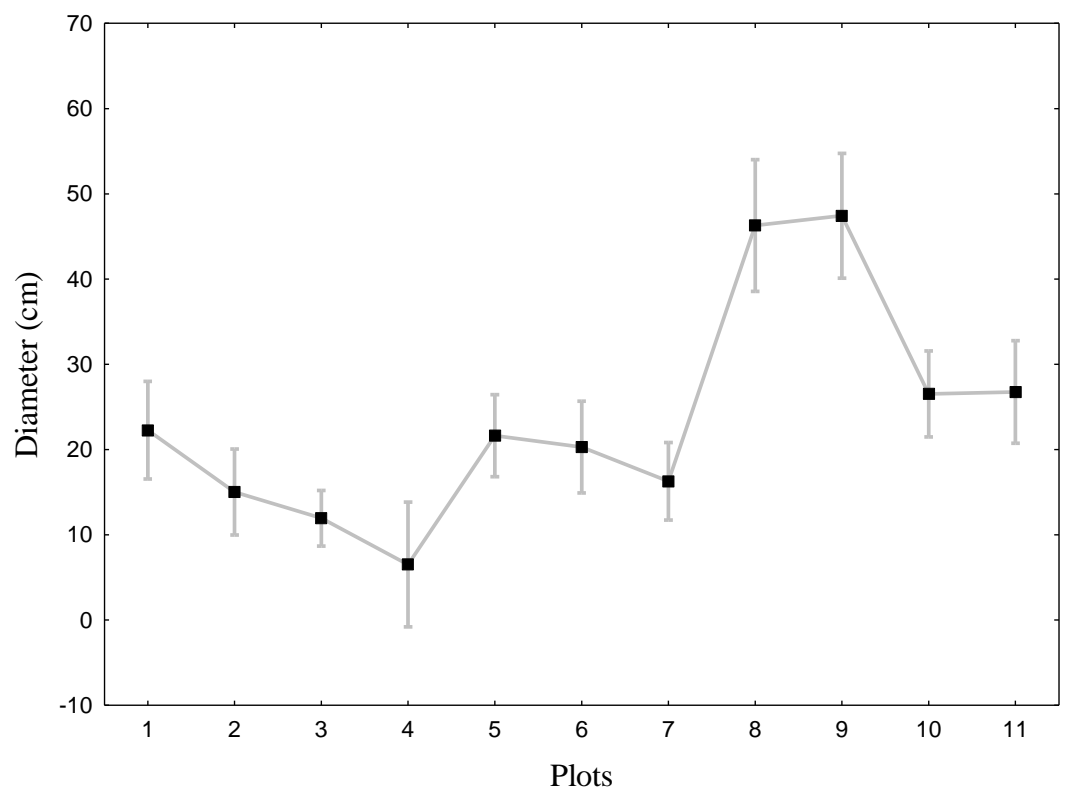

Figure4. Analysis of diameter distribution in the Rio del Rey estuary mangroves. 1, Ngosso 1; 2, Ngosso 2; 3, Bamusso; 4, Kombo'a Mukoko 1; 5, Kombo'a Mukoko 2; 6, Massaka 1; 7, Massaka 2; 8, Andokat 1; 9, Andokat 2; 10, Meme; 11, Mukala Tanda

The variations of diameter distribution, density and basal area are explained by the combination of some environmental factors such as erosion and sedimentation and the type of mangroves sampled. In addition, human activity mainly induce the variation of these parameters. It comes down by the collection of firewood and timber, construction of huts like in the Wouri estuary mangrove [37] and the settlement of some fisheries. In the monospecific stand, intra-specific competition prevent a large number of young plants reaching the mature age and canopy closure is a limiting factor for the growth of individuals [55]. This phenomenon is also observed in the Wouri estuary mangroves [18, 20, 37].

Also, according to [19], selective logging of the species of a certain diameter and even some species according to the needs of residents can consistently interpret the diametric structure and that of other parameters. For [57], mangrove destruction appears in South-east Asia generally as the result of their use for aquaculture, agriculture, the extension of the village, eco-tourism. Particularly in Thailand, the culture of shrimp is the leading cause of mangrove destruction $[58,59]$. 


\section{Conclusion}

The floristic inventory of the Rio del Rey estuary mangroves has highlighted seven major species of African Atlantic mangroves and fourteen accompanying species. The Fabaceae family is the most represented and the locality of Meme is the most diverse. The basal area is low and ranges from 0.06 to $3.68 \mathrm{~m}^{2} \mathrm{ha}^{-1}$. The absolute densities varied from $256 \mathrm{stem} \mathrm{ha}^{-1}$ to $1536 \mathrm{stem} \mathrm{ha}^{-1}$. Analysis of structure parameters shows differences in the sites of plots. These variations are explained by a combination of environmental factors, type of sampled mangroves and the degree of evolution of the stands. From the data of this survey, management strategies shall be implemented to boost the ecosystem resilience to both anthropogenic and climate change stressor expected in the Rio del Rey estuary mangroves. It would be useful to assess the temporal dynamics of this ecosystem and implement conservation measures to regulate human activities which are sum to logging activities and the setting of fisheries and to mitigate the impact of climate change.

\section{REFERENCES}

[1] UNEP (United Nations Environment Programme). Mangroves of Western and Central Africa. UNEP-Regional Seas Programme/UNEP-WCMC, Cambridge, UK, 88 p (2007).

[2] Massó i Alemán S., Bourgeois C., Appeltans W., Vanhoorne B., De Hauwere N., Stoffelen P., Heughebaert A. and Dahdouh-Guebas F. The "mangrove reference database and herbarium". Plant Ecol. Evol. 143, 225-232 (2010).

[3] Spalding M., Kainuma M. and Collins L. World Atlas of Mangroves. Earth scan, UK and USA, p. 319 (2010).

[4] Giri C., Ochieng E., Tieszen L.L., Zhu Z., Singh A., Loveland T., Masek J. and Duke N. Status and distribution of mangrove forests of the world using earth observation satellite data. Global Ecol. Biogeogr. 20, 154-159 (2011).

[5] Kathiresan K. Importance of mangrove ecosystem. Int. J. Mar. Sci. 2 (10), 70 - 89 (2012).

[6] Lee S.Y., Primavera J.H., Dahdouh-Guebas F., McKee K., Bosire J.O., Cannicci S., Diele K., Fromard F., Koedam N., Marchand C., Mendelssohn I., Mukherjee N. and Record S. Ecological role and services of tropical mangrove ecosystems: a reassessment. Global Ecol. Biogeogr.23 (7), 726-743 (2014).

[7] Valiela I., Bowen J.L. and York J.K. Mangrove forests: one of the world's threatened major tropical environments. BioSci. 51 (10), 807-815 (2001).

[8] Friess D.A. and Webb E.L. Variability in mangrove change estimates and implications for the assessment of ecosystem service provision. Global Ecol. Biogeogr. 23, 715-725 (2014).

[9] Nfotabong-Atheull A., Din N. and Dahdouh-Guebas F. Qualitative and quantitative characterization of mangrove vegetation structure and dynamics in a peri-urban setting of Douala (Cameroon): an approach using air-borne imagery. Estuar. Coasts 36, 1181-1192 (2013).

[10] Chimner R.A., Fry B., Kaneshiro M.Y. and Cormier N. Current extent and historical expansion of introduced mangroves on O'ahu, Hawai 'i. Pac. Sci. 60, 377-383 (2006).

[11] Eslami-Andargoli L., Dale P.E.R., Sipe N. and Chaseling J. Mangrove expansion and rainfall patterns in Moreton Bay, Southeast Queensland, Australia. Estuar. Coast. Shelf Sci. 85, 292298 (2009).

[12] Everitt J.H., Yang C., Judd F.W. and Summy K.R. Use of archive aerial photography for monitoring black mangrove populations. J. Coast. Res. 26, 649-653 (2010).

[13] FAO (Food and Agriculture Organization). The world's mangroves 1980-2005. Food and Agricultural Organization of the United Nations Forestry paper 153, Rome, 78 p (2007).

[14] Dahdouh-Guebas F., Van Pottelbergh I., Kairo J.G., Cannicci S. and Koedam N. Human impacted mangroves in Gazi (Kenya): predicting future vegetation based on retrospective remote sensing, social surveys, and distribution of trees. Mar. Ecol. Prog. Ser. 272, 77-92 (2004).

[15] Mmom P.C. and Arokoyu S.B. Mangrove Forest Depletion, Biodiversity Loss and Traditional Resources Management Practices in the Niger Delta, Nigeria. Res. J. Appl. Sci., Eng. Technol. 2 (1), 28-34 (2010).

[16] Rakotomavo A. and Fromard F. Dynamics of mangrove forests in the Mangoky River delta, Madagascar, under the influence of natural and human factors. For. Ecol. Manag. 259, 1161-1169 (2010). 
[17] Ajonina G.N. and Usongo L. Preliminary quantitative impact assessment of wood extraction on the mangroves of Douala-Edea forest reserve, Cameroun. Trop. Biodiv. 7 (2-3), 137-149 (2001).

[18] Din N., Saenger P., Priso R.J., Dibong D.S. and Blasco F. Logging activities in mangrove forest: A case study of Douala Cameroon. Afr. J. Environ. Sci. Technol. 2 (2), 022-030 (2008).

[19] Feka N.Z., Manzano M.G. and Dahdouh-Guebas F. The effects of different gender harvesting practices on mangrove ecology and conservation in Cameroon. Int. J. Biodiv. Sci., Ecosyst. Serv. Manag. 1-14 (2011).

[20] Nfotabong-Atheull A., Din N., Essomè-Koum G.L., Satyanarayana B., Koedam N. and DahdouhGuebas F. Assessing forest products usage and local residents' perception of environmental changes in peri-urban and rural mangroves of Cameroon, Central Africa. J. Ethnobiol. Ethnomed. 7: 41 (2011).

[21] Alongi D.M. Present state and future of the world's mangrove forests. Environ. Conserv. 29 (3), 331-349 (2002).

[22] Duke N., Meynecke J.O., Dittmann S., Ellison A.M., Anger K., Berger U., Cannicci S., Diele K., Ewel K.C., Field C.D., Koedam N., Lee S.Y., Marchand C., Nordhaus I. and Dahdouh-Guebas F. A world without mangroves? Science. 317, 41-43 (2007).

[23] McLeod E. and Salm R.V. Managing Mangroves for Resilience to Climate Change. IUCN, Gland, Switzerland. 64 pp (2006).

[24] Barbier E.B. Valuing ecosystem services as productive inputs. Econ. Policy 177-229 (2007).

[25] Jayatissa L.P., Dahdouh-Guebas F. and Koedam N. A review of the floral composition and distribution of mangroves in Sri Lanka. Bot. J. Linn. Soc. 138, 29-43 (2002).

[26] Ellison J.C. and Zouh I. Vulnerability to climate change of mangroves: assessment from Cameroon, Central Africa. Biology (Basel) 1, 617-638 (2012).

[27] Fusi M., Beone G.M., Suciu N.A., Sacchi A., Trevisan M., Capri E., Daffonchio D., Din N., Dahdouh-Guebas F. and Cannicci S. Ecological status and sources of anthropogenic contaminants in mangroves of the Wouri River Estuary (Cameroon). Mar. Pollut. Bull. 109 (2), 723-733 (2016).

[28] Din N. and Ngollo-Dina E. Perspectives for Sustainable Management of Mangrove Ecosystems in Cameroon. Eur. Trop. For. Res. Netw. News 36 (2), 48-51 (2002).

[29] Din N. and Baltzer F. Richesse Floristique et Evolution des mangroves de l'Estuaire du Cameroun. Afr. Geosci. Rev. 2, 119-130 (2008).

[30] Din N., Priso R.J., Kenne M., Ngollo D.E. and Blasco F. Early growth stages and natural regeneration of Avicennia germinans (L.) Stearn in the Wouri estuarine mangroves (DoualaCameroon). Wetl. Ecol. Manag. 10, 461-472 (2002).

[31] Din N., Ngo-Massou V.M., Kotte-Mapoko E., Essoh-Mongo M.C. and Essomè-Koum G.L. Evolution of Mangrove crabs distribution in the Atlantic coast of Cameroon. In: Ardovi C. (ed). Crabs: Global diversity, behavior and environmental threats. Nova publishers, New York, Pp 191 (2014).

[32] Din N., Ngo-Massou V.M., Essomè-Koum G.L., Kottè-Mapoko E., Emanè J.M., AkusaAkongnwi D. and Tchoffo R. Local Perception of Climate Change and Adaptation in Mangrove Areas of the Cameroon Coast. J. Water Resour. Prot. 8, 608-618 (2016).

[33] Simon L.N. and Raffaelli D. Assessing ecosystem effects of small-scale cutting of Cameroon mangrove forests. J. Ecol. Nat. Environ. 4(5), 126-134 (2012).

[34] Ngo-Massou V.M., Essome-Koum G.L., Ngollo-Dina E. and Din N. Composition of macrobenthos in the Wouri River estuary mangrove, Douala, Cameroon. Afr. J. Mar. Sci. 34, 349-360 (2012).

[35] Ngo-Massou VM, Essomè-Koum GL, Kotte ME, Din N. Biology and Distribution of Mangrove Crabs in the Wouri River Estuary, Douala, Cameroon. J. Water Res. Prot. 6, 236-248 (2014).

[36] Ngo-Massou V.M., Kenne M. and Dongmo A.B. Effect of Anthropogenic Activities on Mangrove Crab Diversity in Cameroon Atlantic Coast. Int. J. Res. Stud. Biosci. 4(4), 1-12 (2016).

[37] Din N. Mangrove du Cameroun: statut écologique et perspectives de gestion durable. Thèse d'Etat, Univ. Yaoundé I, Cameroun. 268 p (2001). 
[38] Ndema-Nsombo E., Sone-Essoh W., Ajonina G., Etamè J., Din N. and Diyouke-Mibog E. Dynamique de croissance et taux de mortalité de Rhizophora spp. dans les mangroves de l'estuaire du Rio del Rey: Site de Bamusso (Sud-Ouest Cameroun). J. Appl. Biosci. 85, 78247837 (2015).

[39] Ndema-Nsombo E. Influence de la dégradation de la végétation sur les caractéristiques morphologiques, physico-chimiques et le stock de carbone des sols des mangroves du Cameroun. Thèse doctorat $\mathrm{PhD}$, Univ. Douala, Cameroun, 115 p (2016).

[40] Ngole-Jeme V.M., Fonge B.A., Tabot P.T. and Mumbang C. Impact of logging activities in a tropical mangrove on ecosystem diversity and sediment heavy metal concentrations. J. Coast. Conserv. 20, 245-255 (2016).

[41] Ludwig J.A. and Reynolds J.F. Statistical Ecology, A primer on methods and computing. John Wiley and Sons, New York, USA (1988).

[42] Saenger P. and Bellan M.F. The mangrove vegetation of the Atlantic Coast of Africa. (Université de Toulouse Press: Toulouse.) 96 pp (1995).

[43] Spalding M., Blasco F., Field C. "World Mangrove Atlas". (International Society for Mangrove Ecosystems: Okinawa, Japan.) 180 pp (1997).

[44] Parani M., Lakshmi M. and Senthilkumar P. Molecular phylogeny of mangroves V. Analysis of genome relationships in mangrove species using RAPD and RFLP markers. Theor. Appl. Genet. 97, 617-25 (1998).

[45] Kathiresan K. and Bingham B.L. Biology of mangroves and mangrove ecosystems. Adv. Mar. Biol. 40, 81-251 (2001).

[46] Duke N.C. Australia's Mangroves: the Authoritative Guide to Australia's Mangrove Plants. St Lucia, Australia: University of Queensland, 29-39 (2006).

[47] Tomlinson P.B. The botany of mangroves. Cambridge University Press, 413 p (1986).

[48] Heads M. Seed plants of Fiji: an ecological analysis. Biol. J. Linn. Soc. 89: 407-31 (2006).

[49] Mu M.R., Jiang Q.L. and Wang W.Q. Comparison of leaf chloride content and leaf traits between true mangrove plants and semi mangrove plants. J. Plant Ecol. (Chinese Version) 31, 497-504 (2007).

[50] Wang L., Mu M., Li X., Lin P., Wang W. Differentiation between true mangroves and mangrove associates based on leaf traits and salt contents. J. Plant Ecol. 1-10 (2010).

[51] Blasco F., Saenger P. and Janodet E. Mangroves as indicators of coastal change. Cantena 27, 167-178 (1996).

[52] Van Campo E. and Bengo M.D. Mangrove palynology in recent marine sediments off Cameroon. Mar. Ecol. 208 (2-4), 315-330 (2004).

[53] Nfotabong-Atheull A., Din N., Longonje S.N., Koedam N. and Dahdouh-Guebas F. Commercial activities and subsistence utilization of mangrove forests around the Wouri estuary and the Douala-Edea reserve (Cameroon). J. Ethnobiol. Ethnomed. 5, 35 (2009).

[54] Cintrón C., Schaeffer-Novelli Y. Methods for studying mangrove structure. In: Snadaker SC, Snaedaker JG (eds). The mangrove ecosystem research methods. UNESCO, Paris, France, pp 91-113 (1984).

[55] Mohamed M.O.S., Neukermans G., Kairo J.G., Dahdouh-Guebas F. and Koedam N. Mangrove forests in a peri-urban setting: the case of Mombasa (Kenya). Wetl. Ecol. Manag. 17, 243-255 (2009).

[56] Satyanarayana B., Raman A.V., Mohd-Lokman H., Dehairs F., Sharma V.S. and DahdouhGuebas F. Multivariate methods distinguishing mangrove community structure of Coringa in the Godavari Delta, East coast of India. Aquat. Ecosyst. Health Manag. 12(4), 401-408 (2009).

[57] Farnsworth E.J. and Ellison A.M. The global conservation status of mangroves. Ambio 26, $328-$ 334 (1997).

[58] Vandergeest P., Flaherty M. and Miller P. A political ecology of shrimp aquaculture in Thailand. Rural Sociology 64, 573-596 (1999).

[59] Barbier E.B., Sathirathai S. and Elgar E. Shrimp Farming and Mangrove Loss in Thailand. Aquac. Inter. 13, 283-290 (2005). 